\title{
Preface: Special Issue arising from the meeting in Mainz, Germany, of the Fluvial Archive Group
}

\author{
D.R. Bridgland ${ }^{1} \&$ F. Sirocko ${ }^{2}$ \\ ${ }^{1}$ Corresponding author; Department of Geography, Universiry of Durham, Durham DH1 \\ 3LE. email contact: d.r.bridgland@durham.ac.uk \\ 2 Institut für Geowissenschaften, Johannes Gutenberg-Universität, \\ Mainz, Johann-Joachim-Becher-Weg 21, 55099 Mainz, Germany; \\ e-mail: sirocko@mail.uni-mainz.de
}

Manuscript received: September 2002; accepted: September 2002

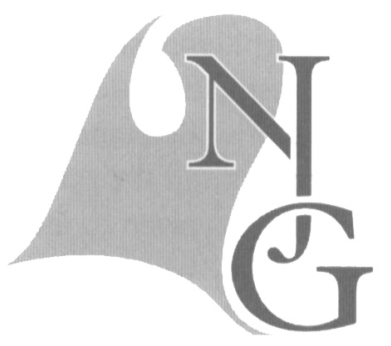

The Fluvial Archives Group (FLAG) was formed in 1996 under the auspices of the Quaternary Research Association. It held its first meeting in Durham, UK, in December of that year, followed by meetings in Arcen, the Netherlands (1997), Cheltenham, UK (1998), Mainz, Germany (2000), and, most recently, Clermont-Ferrand, France (2002). A selection of papers arising from the meeting in Cheltenam was pubished in 2001 under the title 'River basin sediment systems: archives of environmental change' (Maddy, Macklin and Woodward, 2001). In 1999 a FLAG session was organized within the framework of the 15th INQUA Congress in Durban, South Africa, which led to an issue of Quaternary International (volume 79, May 2001). This present issue of the Netherlands Journal of Geosciences/Geologie en Mijnbouw represents papers arising from the 2000 FLAG meeting in Mainz.

At the time of writing FLAG has more than 250 members in 45 countries.

\section{Scope of FLAG interests and activities}

The types of data that can be regarded as part of the fluvial record, and therefore within the scope of FLAG, are broad and encompass several disciplines. Thus geomorphologists, sedimentologists, stratigraphers, geophysicists, archaeologists, palaeontologists and palaeoecologists are all to be found within its ranks. The linking factor is the fluvial environment, although that should not be seen as a restriction; comparison and correlation with other environments are imperatives for many studies and most FLAG members by no mean restrict their activities to fluvial records.

The stated aims of the Fluvial Archives Group are:

- To promote the value of investigating fluvial archives through the production of widely available and readily accessible published information;

- To establish a forum for the exchange of information and ideas;

- To identify foci for future research and, in particular, to identify the gaps in current knowledge;

- To facilitate joint 'focused' initiatives to formulate strategies for addressing problems.

To address these aims several themes (foci) have evolved, essentially differing in terms of timescale. At one extreme, Focus 1 addresses Long Terrestrial Fluvial Records spanning the whole Quaternary and even further back in time. This theme is being progressed by means of an International Geological Correlation Programme (IGCP) project (No. 449), entitled 'Global Correlation of Late Cenozoic fluvial deposits' that was established from within FLAG and is closely integrated with the activities of the group. Several papers in the special issue are identified as contributions to IGCP 449. Focus 2 addresses Fluvial activity and crustal instability, which is independent of timescale considerations but, for obvious reasons, tends to involve observations over long periods. Focus 3 is synonymous with an INQUA project entitled 'Fluvial Response to Rapid Environmental Change during the last two interglacial-glacial cycles'. On the shortest timescale, Focus 4 is concerned with 
Holocene fluvial system response to frequent and rapid periods of environmental change: identification and modelling of forcing factors.

\section{The meeting in Mainz}

The FLAG meeting in 2000 was held at the Insitute for Geoscience,University of Mainz, Germany. Two days of lectures and a poster session were followed by a boat excursion along the Rhine and a visit to the Eifel maar lakes. Approximately 80 participants attended sessions devoted to the four focuses listed above. Each session started with presentations on the geological/geomorphological description of river sediment archives and ended with modelling-oriented studies aimed at understanding the processes that form fluvial sediments and their development in time. Particular attention was given to the problems of dating clastic river sediments, which is notoriously difficult. Luminescence techniques have provided some very promising advances, but for sediments older than $150 \mathrm{ka}$, dating remains difficult for anything but relative methods.

The contents of the special issue are arranged broadly according to which FLAG focus they address, such that longer timescale studies (Focus 1) appear before those pertaining to shorter timescales or to modern processes. The first paper, by Bridgland and Maddy, is a review of published baseline knowledge of Late Cenozoic fluvial records at the outset of IGCP 449. Westaway's two papers relate fluvial terrace archives to the Earth's crustal activity. Relevant to both Focus 1 and 2, his work seeks to use the fluvial record to understand crustal evolution and mechanisms. Similarly, Maddy considers crustal movements, base-level and climate in his interpretation of the record from Britain's longest river, the Severn. Schreve and Bridgland promote mammalian biostratigraphy as a means for correlation and relative dating, in a study that seeks to compare the British and German records from the Middle Pleistocene. The paper by Matoshko, Gozhik and Ivchenko summarizes, probably for the first time in English, the Quaternary archive of the River Dnieper. This is important data from the northern Black Sea region, recognized as a key area for fluvial Quaternary archives; as such this paper is an important contribution to IGCP 449.

The shorter timescale studies commence with a discussion by Veldkamp, van den Berg, van Dijke and van den Berg van Saparoea of morphogenetic process controls in the upper reaches of the Aller Valley in north Germany. Cohen, Stouthamer and Berendsen quantify late Pleistocene rates of tectonic movements along the river Meuse. Gaigalas and Dvareckas provide a description of the fluvial archive from Lithuania, where the extant river systems have developed since deglaciation during the most recent climatic cycle. Nevertherless, an impressive staircase of fluvial terraces is recognized from this recently glaciated area (see their Figure 2). This is followed by Straffin and Blum's appraisal of fluvial response in Bergundy, France, to Holocene climate change and anthropogenic influences. In the final paper, Sirocko, Szeder, Seelos, Lehne, Diehl, Rein and Schneider discuss possible impacts from recent and subrecent tectonic and halocinetic movements in the north German basin on the development of rivers and landscape morphology.

Frank Sirocko was originally to have been joined, as guest editor of this special issue, by Dariusz Krzyszkowski, of WSP Stupsk, Poland, who was a tireless supporter of FLAG in its early days and of considerable assistance in the inception of IGCP 449. To our great regret, Dariusz was taken ill very suddenly, in September 2000, while participating in the Subcommission of European Quaternary Stratigraphy meeting in Bari, Southern Italy. His recovery, from what was clearly a severe stroke, progresses slowly. The meeting in Mainz was the last time many of us saw him fit and well; we miss his energy and enthusiasm and look forward to the time when he can participate fully in the activities of the FLAG community once again. We wish to dedicate this issue to Dariusz and to his future return to the activities of our group.

Details of FLAG focuses can be found on the website (http://www.qra.org.uk/FLAG) or by contacting the focus leaders, as detailed below:

\section{Focus 1 (IGCP 449)}

Global correlation of Late Cenozoic fluvial deposits

David Bridgland [d.r.bridgland@durham.ac.uk]

\section{Focus 2}

Fluvial Activity and Crustal Instability

Darrel Maddy [darrel.maddy@ncl.ac.uk]

\section{Focus 3 (INQUA)}

Fluvial Response to Rapid Environmental Change during the last two interglacial-glacial cycles: The north-west European Fluvial Archive

Jef Vandenberghe [vanj@geo.vu.nl]; Darrel Maddy [darrel.maddy@ncl.ac.uk]

\section{Focus 4}

Holocene fluvial system response to frequent and rapid periods of environmental change: identification and modelling of forcing factors

David Passmore [d.g.passmore@ncl.ac.uk] 